\title{
DETERMINING THE CONDITIONS OF SUSPENDED SEDIMENT FLOW IN A DRAINAGE SYSTEM
}

\author{
Bogusław Michalec, Mateusz Strutyński \\ Department of Hydraulic Engineering and Geotechnics, University of Agriculture in Krakow, Al. Adama Mickiewicza 24/28, \\ 30-059 Kraków
}

\begin{abstract}
Aim of the study

In this paper we attempt to determine the sediment flow conditions in the drainage system of the barrage in Łaczany on the Wisła (Vistula) river. To this end, the distribution of suspended sediment concentration in the cross-sections of draining ditches was developed; the concentration profiles of suspended sediment in individual cross-sections of the main ditch were elaborated; and the assessment of the concentration variation in the concentration profiles in the determined cross-sections on the entire length of the main drainage ditch $\mathrm{R}$ in the drainage system Łączany was carried out.
\end{abstract}

\begin{abstract}
Material and methods
Four measurement cross-sections p-1, p-2, p-5 and p-7 were determined in the ditch R of the system, and three measurement cross-sections were determined on the tributaries to the ditch R. Point measurements of volumetric concentration of suspended sediment in cross-sections were conducted in accordance with the methodology of water sampling using bottle bathometers. Measurements were also made across the entire cross-section using a pre-calibrated Portable Suspended Solids Monitor 740 instrument produced by Partech company. The results of these measurements enabled the determination of the correction factor $(\mathrm{k})$ for each of the measurement cross-sections.
\end{abstract}

\begin{abstract}
Results and conclusions
It was found that the values of this coefficient $(\mathrm{k})$ range from 1.188 to 1.328 , which means that in calculations of suspended sediment transport in the ditches of the drainage system, tested using the so-called normal method, it is necessary to take into account the variation of concentration of this sediment in the cross-section of the ditch. The differences in the volume concentration of suspended sediment in hydrometric divisions (verticals) were also found. These concentrations, measured in surface layers, regardless of the height of vertical filling, represented on average about $60 \%$ of the value of the concentration measured in bottom layers of the verticals, i.e. about $5 \mathrm{~cm}$ above the bottom
\end{abstract}

Keywords: ditch, concentration profiles of suspended sediment, concentration profile

\section{INTRODUCTION}

Erosion processes and sediment transport conditions in river systems are the main issues of well-known and described phenomena. Researchers are much less focused on problems related to the operation of drainage systems due to sediment transport and silting processes. Degradation of drainage ditches is mainly caused by the processes of erosion and sedimentation within their riverbed, whereas the erosion processes

凶e-mail:rmmichbo@cyf-kr.edu.pl 
in catchments drained by these ditches contribute to the transport of mineral material, which for ditches ending in a retention reservoir or a pumping station, becomes deposited therein. Retention and deposit of sediment in these reservoirs contributes to their shallowing, as well as hindering or preventing their proper operation. Silting the ditches of drainage systems is one of the factors that limit the proper use of these systems. As a result of the accumulation of eroded earth material, technical equipment and engineering objects located in the drainage system of the given watercourse are damaged. According to Pierzgalski et al (2012), accelerated decapitalization of drainage facilities in Poland was caused, among others, by silting the bottom of the ditches with deposits from the catchment, overgrowing the bottom of the ditches with rush vegetation, and various types of failures, such as the silting of culverts, or washing down of the escarpment. The study by Pierzgalski et al (2012), regarding the verification of drainage systems for flood safety in the Central Vistula (Wisła) water region, stated that "the effect of the above-mentioned processes was the exclusion of drained complexes from the records of operation and maintenance". Many Polish scientific papers draw attention to the need for proper exploitation of drainage systems (among others, Pierzgalski et al., 2012; Walczak et al., 2015; Liberacki and Olejniczak, 2013). Operating neglect leads to poor condition of the structures. This was demonstrated by Liberacki and Olejniczak (2013) in tests of the technical condition of drainage facilities located on the streams of the Zielonka Forest. Authors indicate the need for proper maintenance of the ditches within drainage systems (Kiryluk, 2013), and water facilities (Rytlewski, 2007; Kiryluk, 2014; Walczak et al., 2015), and draw attention to a reduction in financial expenditure allocated for the maintenance of drainage facilities, which unfortunately causes their increasing decapitalization (Walczak et al., 2015). The economic aspect of maintaining water management systems, including drainage systems, presented in the Technical Report Series entitled "Sediment Deposits in Drainage Ditches" (Forester and Girmai, 1980), indicates the need to include in the maintenance costs also the works related to the reduction of erosion processes. These processes contribute to the deposition of sediment in the drainage system, the re- moval of which generates costs. This report indicates that the USLE method should be used to determine the intensity of erosion processes in the drainage system. The authors of the present work believe that it is also necessary to properly determine the sediment delivery ratio, which will allow for correct determination of sediment transport in the drainage system based on the results of calculations using the USLE method. Proper determination of the sediment delivery ratio can be achieved as a result of verification of the existing methods for determining that ratio, or developing new ones, but this requires testing sediment transport in drainage systems. Unfortunately, no sediment transport measurements are carried out as part of the regular operation of drainage systems. Such measurements, if they had been conducted, were mainly incidental in nature, as they were carried out at random and in the short measurement period, while their purpose was to deliver an expert opinion or to develop a conceptual solution.

Ensuring proper operation of drainage systems, including their proper use, as well as adequate procedures, including carrying out repairs and maintenance of individual system components, requires extensive recognition of surface erosion conditions of the drained areas, conditions of inflow of erosion products to ditches, as well as their transport and sedimentation in the ditches. The paper attempts to determine the sediment flow conditions in the drainage system of the barrage in Łączany on the Wisła (Vistula) river. As part of the research, specific objectives were adopted, including determining the distribution of suspended sediment concentration in the drainage system ditches, developing sediment concentration profiles in individual cross-sections of the main ditch, and assessing the differences in concentration values in the concentration profiles in designated cross-sections along the entire length of the main ditch $\mathrm{R}$ of the drainage system in Łączany.

\section{RESEARCH METHODOLOGY}

The research was carried out in the main ditch $\mathrm{R}$ and its two tributaries, belonging to the drainage system of the Laczany barrage on the Vistula river (see: Fig. 1). A detailed description of the system is contained in the works of Michalec (2012), Michalec 


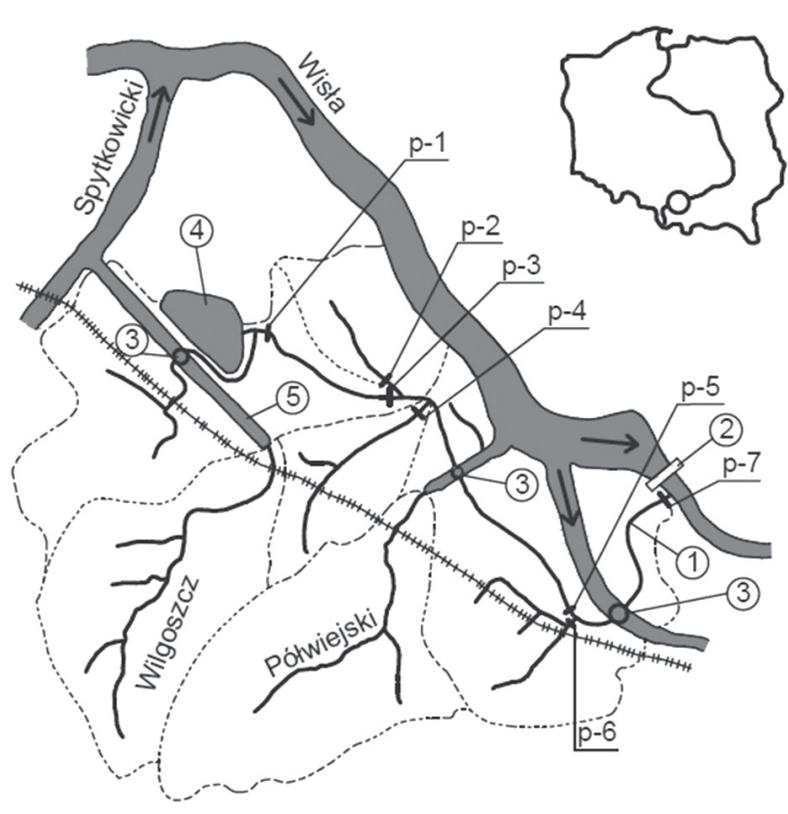

Fig. 1. Łączany draining system with marked cross-sections (from p-1 to p-7) and corresponding sub-catchments. Symbols in the figure: 1 - ditch R, 2 - Łączany barrage, 3 - siphons of ditch R, 4 - Kasztelan pond, 5 - Małopolski canal

et al. (2013) and Majerczyk and Michalec (2017). The system was constructed on the right bank of the Vistula river. Its purpose is to eliminate the effects of damming the Vistula waters by the water barrage in Łączany, built in 1955-1961 (Budowa pompowni... 1977). The $\mathrm{R}$ ditch of the drainage system, $8240 \mathrm{~m}$ long, has a beginning in the embankment lock in the right bank of the Vistula along the lower stand of the Łaczany barrage, and its end is in the region of the kanał Małopolski (canal).

Measurement cross-sections p- $1, \mathrm{p}-2, \mathrm{p}-5$ and $\mathrm{p}-7$ were determined in the ditch $\mathrm{R}$, and the sections with numbers $p-3, p-4$ and $p-6$ were marked on the tributaries to the ditch $\mathrm{R}$. The determined cross-sections close the sub-catchments of the $\mathrm{R}$ ditch catchment. In the seven cross-sections, thus defined, hydrometric measurements of elevated sediment concentration were conducted. The measurements of volumetric concentration of suspended sediment were carried out in accordance with the methodology of water sampling using bottle bathometers (Instrukcja wykonania... 1990; Brański, 1966). Water sampling, with the use of a bottle pickup, was executed at one point of the ditch cross-section, i.e. in its axis, at a depth of approx. $5 \mathrm{~cm}$. Measurements were made both at the water sampling point using a bottle bathometer, as well as for the entire cross-section. The sediment concentration measurements across the entire section were carried out using a previously calibrated Portable Suspended Solids Monitor 740 instrument produced by Partech. This measurement, which is called multi-point measurement (Brański, 1975), was carried out in the same hydrometric divisions that were designated for measuring the water flow rate, because the measurements of water flow rate and measurements of the concentration of sediment were carried out simultaneously.

In accordance with the instructions for use of the photo-optical device, calibration was performed in distilled water, and in the prepared water-rubble solutions. The calibration covered the volumetric concentration of the sediment up to 0 to $500 \mathrm{~g} \cdot \mathrm{m}^{-3}$. Samples of suspended sediment were prepared from sediments sampled from the bottom of the ditch R. Due to the water coloration during measurements, among others resulting from wastewater discharges into the ditch, and to rotting vegetation, it turned out necessary to verify the obtained results of photo-optical measurements based on the results of bathometric measurements. The results of point concentration measurements, performed with a bathometer and a photo-optical device, were used for the purpose. It turned out necessary to establish the correlation of volumetric concentration of suspended sediment at the sampling point determined by the bathometric method $\left(\mathrm{C}_{\mathrm{pB}}\right)$ as a function of the concentration of this sediment at the sampling point determined by the photo-optical method $\left(\mathrm{C}_{\mathrm{pF}}\right)$. This correlation enabled the conversion of the volumetric concentration of sediment determined at individual points of hydrometric divisions, measured with a photo-optical device, into the value of concentration corresponding to bathometric measurements.

Based on the results of measurements of sediment concentration carried in individual measurement cross-sections, a correlation was established for each cross-section between the sediment volumetric concentration $\left(\mathrm{C}_{\mathrm{pB}}\right)$, determined on the basis of point measurements, and the overall sediment volumetric concentration $\left(\mathrm{C}_{\mathrm{pB}}\right)$. The correlations thus developed 
enabled the determination of the correction factor $(\mathrm{k})$ for each of the measurement cross-sections.

Statistical significance of the correlation coefficient for the assumed significance level $\alpha=0.05$ was determined for all the developed correlations. The null hypothesis $\left(\mathrm{H}_{0}\right)$ was adopted: the true value of the correlation coefficient is $0(R=0)$, which is equivalent to no correlation. In order to verify this hypothesis, statistics were adopted (Bates, 1988) in the following form:

$$
t=\frac{R \sqrt{n-2}}{\sqrt{1-R^{2}}}
$$

where:

$$
\begin{aligned}
& R \text { - is the value of the Pearson correlation coeffi- } \\
& \text { cient, determined for the sample, } \\
& n \text { - sample size. }
\end{aligned}
$$

Simultaneous measurements of sediment concentration and water flow velocity measurements made it possible to determine the average daily sediment transport intensity corresponding to the average daily water flow rate in a given measurement cross-section.

\section{RESULTS}

Sediment concentration and water flow velocity measurements in drainage system ditches were made in fourteen measurement series. These measurements were made in the period from May 2015 to November 2016. Based on the results of point concentration measurements made with the use of a bathometer and a photo-optical device, the correlation was developed for volumetric concentration of suspended sediment at the sampling point determined by the bathometric method $\left(C_{p B}\right)$, as a function of concentration of this sediment determined by the photo-optical method $\left(C_{p F}\right)$ (see: Fig. 2).

The obtained Pearson's R linear correlation coefficient, for the correlation shown in Figure 2, is 0.9719. Its value indicates a very strong rectilinear relationship between two measurable features - i.e. $C_{p B}$ and $C_{p F}$. If the null hypothesis were true, the t-statistics would have a Student's t distribution with $d f=(\mathrm{n}-2)$ degrees of freedom. The value of $t$ calculated using the formula (1) is 38.77 , and the critical value of $t_{0}$ at the significance level $\alpha=0.05$ is 1.9961 . Therefore, the absolute value of $\mathrm{t}$ is greater than the critical value of $t_{0}$, so the $H_{0}$ hypothesis is rejected, which means that the correlation is significant at the adopted level of $\alpha=0.05$. The correlation, presented in Figure 1, allowed the conversion of the volumetric concentration of sediment determined at individual points of hydrometric divisions, measured with a photo-optical device, to the concentration value corresponding to the bathometric measurements. The direction coefficients of the developed linear regression equations were determined for the data thus prepared. Regression equations were elaborated for the volumetric concentration of sediment measured at the sampling point $\left(C_{p B}\right)$, i.e. independent variables, and the volumetric concentration of sediment across the entire ditch cross-section $\left(C_{p B}\right)$, i.e. dependent variables. Figure 3 shows an example of the correlation $C_{p B}=f\left(C_{p B}\right)$, developed for cross-section $\mathrm{p}-2$.

The directional coefficients of the equations are the correction coefficients (k), which together with the

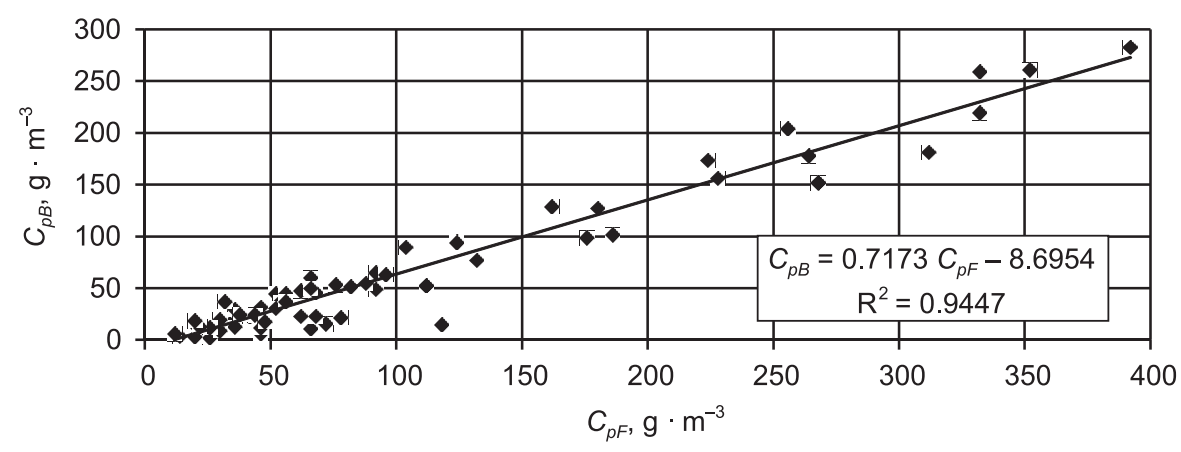

Fig. 2. Correlation of volumetric concentration of suspended sediment at the sampling point determined by the bathometric method $\left(C_{p B}\right)$, as a function of concentration of this sediment determined by the photo-optical method $\left(C_{p F}\right)$ 


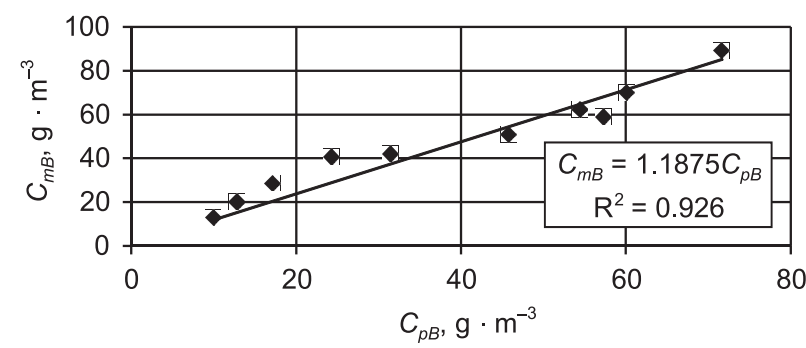

Fig. 3. Correlation of volumetric concentration of sediment in the entire cross-section of the ditch $\left(\mathrm{C}_{\mathrm{mB}}\right)$ to the volumetric concentration of sediment at the sampling point $\left(\mathrm{C}_{\mathrm{pB}}\right)$ developed for the measurement cross-section p-2

values of Pearson's R linear correlation coefficients are given in Table 1. The absolute values of the $t$ statistics are greater than the critical values of the $t_{0}$ test. This means that the developed correlations are statistically significant at the adopted level of $\alpha=0.05$. The correction factor $(\mathrm{k})$, elaborated for each of the cross-sections, was used in the calculation of the average annual concentration of suspended sediment in the entire measurement cross-section. The results of these computations are contained in the paper by Michalec (2018).

The results of concentration measurements using a photo-optical device in measurement cross-sections enabled the development of concentration profiles. The values of volumetric concentration of suspended sediment, determined using the photo-optical method $\left(C_{F}\right)$, were converted using the correlation shown in Figure 2 into the values of this concentration $\left(C_{B}\right)$, corresponding to the bathometric concentration. Due to the possibility of comparing the developed profiles for different flows in each of the measurement cross-sections, these profiles were developed using the relative depth and relative volumetric concentration of sediment, with the relative volume concentration of sediment being calculated as the ratio of the concentration at a given height of the hydrometric vertical and the concentration at the lowest point of this vertical.

Figure 4 presents examples of concentration profiles, developed on the basis of measurements in

Table 1. Correlation coefficients " $\mathrm{k}$ " determined for each measurement cross-section

\begin{tabular}{|l|c|c|c|c|c|c|c|}
\hline \multicolumn{1}{|c|}{ Cross-section number } & $\mathrm{p}-1$ & $\mathrm{p}-2$ & $\mathrm{p}-3$ & $\mathrm{p}-4$ & $\mathrm{p}-5$ & $\mathrm{p}-6$ & $\mathrm{p}-7$ \\
\hline Correlation coefficient " $\mathrm{k}$ " & 1.284 & 1.188 & 1.241 & 1.237 & 1.221 & 1.328 & 1.211 \\
\hline Pearson's R correlation coefficient & 0.9685 & 0.9623 & 0.9898 & 0.9935 & 0.9966 & 0.9907 & 0.9967 \\
\hline Sample size $\mathrm{n}$ & 10 & 10 & 10 & 9 & 10 & 6 & 10 \\
\hline $\mathrm{t}$ statistics & 10.99 & 10.01 & 19.70 & 23.05 & 34.18 & 14.57 & 34.97 \\
\hline Critical vale of t statistics $t_{0}$ for $\alpha=0.05$ & 2.306 & 2.306 & 2.306 & 2.365 & 2.306 & 2.5706 & 2.306 \\
\hline
\end{tabular}

a)

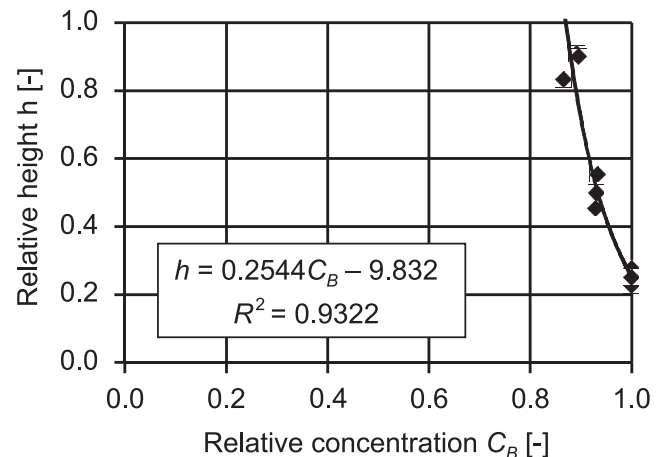

b)

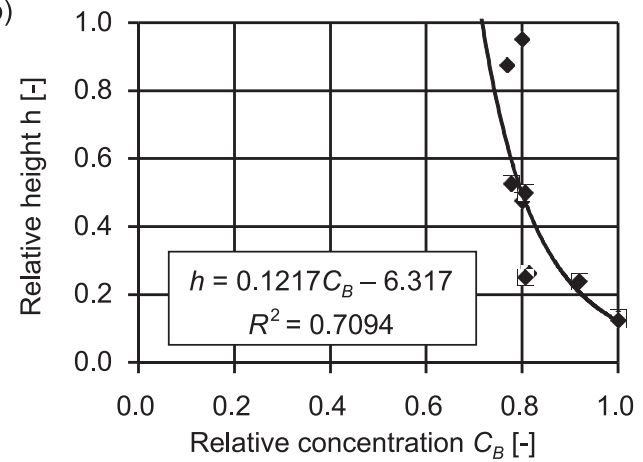

Fig. 4. Profiles of sediment concentration - measurement cross-section p-5; a) maximum height $h_{\max }=0.22 \mathrm{~m}$, a) maximum height $h_{\max }=0.42 \mathrm{~m}$ 
cross-section p-5 at low water levels and low volumetric concentrations of sediment. Figure 4a. presents the concentration profile, developed on the basis of flow rate in this section at $0.007 \mathrm{~m}^{3} \cdot \mathrm{s}^{-1}$, which corresponded to the maximum height in the cross-section, amounting to $0.22 \mathrm{~m}$, whereas Figure $4 \mathrm{~b}$. shows the concentration profile, developed based on flow rate of $0.032 \mathrm{~m}^{3} \cdot \mathrm{s}^{-1}$, which corresponded to a maximum height in the cross-section being $0.42 \mathrm{~m}$.

In turn, Figure 5.a presents the concentration profile in section p-5, developed for a flow rate of $0.064 \mathrm{~m}^{3} \cdot \mathrm{s}^{-1}$, which corresponded to the maximum height in the cross-section being $0.61 \mathrm{~m}$; whereas Figure 5.b) shows concentration profile, developed for $0.072 \mathrm{~m}^{3} \cdot \mathrm{s}^{-1}$ flow rate with a maximum height in the cross-section amounting to $0.94 \mathrm{~m}$.

The minimum and maximum values of relative height on the presented concentration profiles require some explanation. At low fillings in the ditch bed, concentration measurements close to the surface of the water table and close to the bottom surface proved impossible due to the limited dimensions of the photo-optical sensor. In order to enable measurement results that would not be burdened with the error caused by turbulence of bottom sediments in the cross-section, measurements in the bottom zone were taken at the maximum lowest setting of this sensor, at an absolute height of about $5 \mathrm{~cm}$ above the bottom. Therefore, at low fillings, a measurement at a height of $5 \mathrm{~cm}$ above the bottom meant approx. 0.2 and even 0.3 relative vertical height at low filling levels (see: Fig. 4), and at higher levels, it amounted to approx. 0.05-0.1



relative depth (see: Fig. 5). The same effect was evident in the case of concentration measurements close to the surface of the water table.

The shape of the concentration profile curves indicates that at lower fillings (see: Fig. 4), at which the maximum sediment concentrations were $72 \mathrm{~g} \cdot \mathrm{m}^{-3}$ (see: Fig. $4 \mathrm{a}$ ) and $66 \mathrm{~g} \cdot \mathrm{m}^{-3}$ (see: Fig. $4 \mathrm{~b}$ ) relative variation of sediment concentration in the given vertical is much smaller than in the case of concentration profiles developed for larger fillings in the same cross-section (see: Fig. 5). When the maximum filling in the p-5 cross-section was $0.61 \mathrm{~m}$ (see: Fig. $5 \mathrm{a}$ ), then the maximum concentration of sediment was $396 \mathrm{~g} \cdot \mathrm{m}^{-3}$, whereas at the maximum filling amounting to $0.94 \mathrm{~m}$ (see: Fig. 5b) the maximum concentration of sediment was $508 \mathrm{~g} \cdot \mathrm{m}^{-3}$. Variations in sediment concentration values associated with the change in water height in the cross-section, and thus with the change in the maximum concentration in the cross-section, were found in each measurement profile. Following from the analysis of the developed concentration profiles for the seven measurement cross-sections, it was found that a significant variation in the concentration value in the concentration profile increases with the increase in the filling (water height) of the ditch, which corresponds to the increase in the flow rate.

Changes in the variation of relative concentration values in the concentration profile in the main ditch $\mathrm{R}$ were found, from its end section, i.e. $\mathrm{p}-1$, to its beginning, i.e. section $\mathrm{p}-7$. In the cross-sections of the $\mathrm{R}$ ditch, i.e. in the cross-sections p-2, p-5 and p-7 (see: Fig. 6), the value of relative surface concentrations is

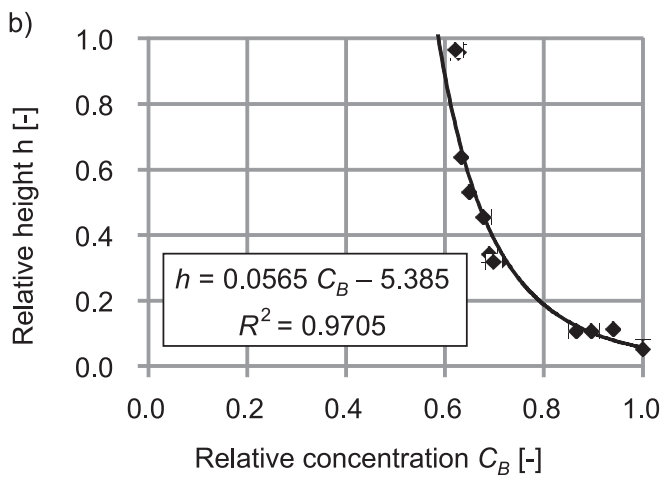

Fig. 5. Profiles of sediment concentration - measurement cross-section p-5; a) maximum height $h_{\max }=0.61 \mathrm{~m}$, a) maximum height $h_{\max }=0.94 \mathrm{~m}$ 
Michalec, B., Strutyński, M. (2019). Determining the conditions of suspended sediment flow in a drainage system. Acta Sci. Pol., Formatio Circumiectus, 18 (3), 49-58. DOI: http://dx.doi.org/10.15576/ASP.FC/2019.18.4.49

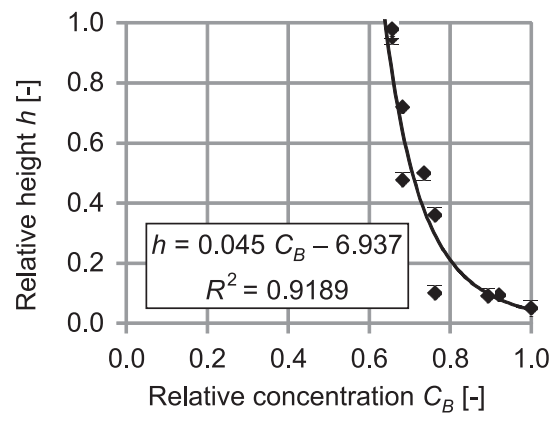

a) cross-section $p-1$

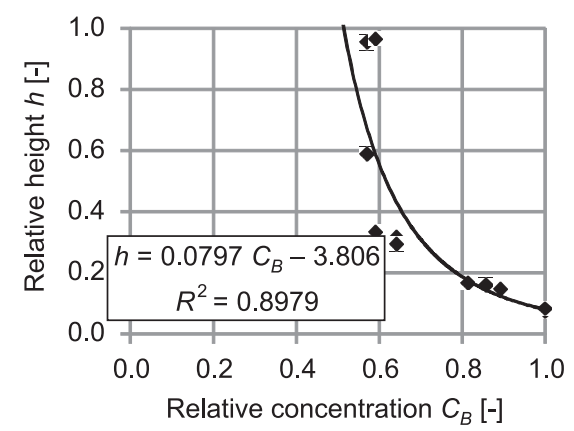

c) cross-section p-3

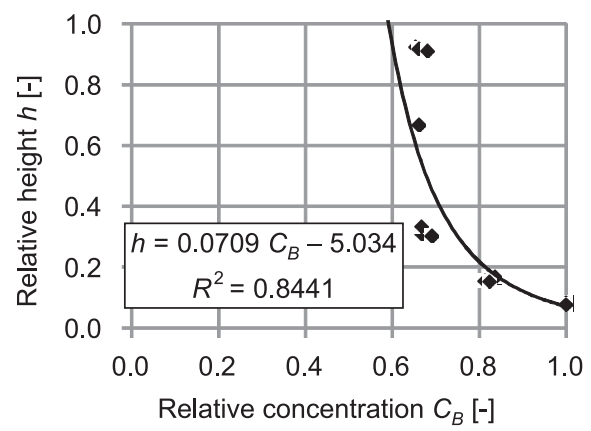

e) cross-section p-5

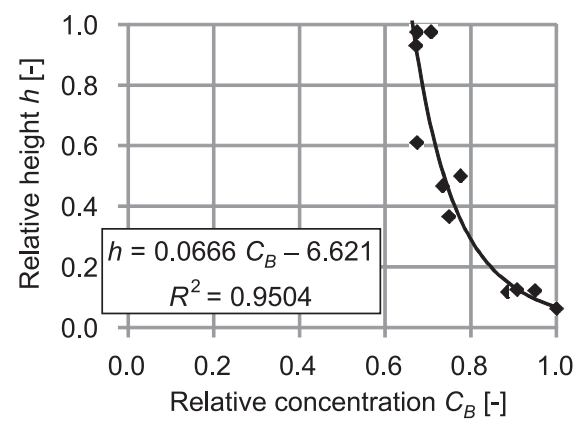

g) cross-section $p-7$

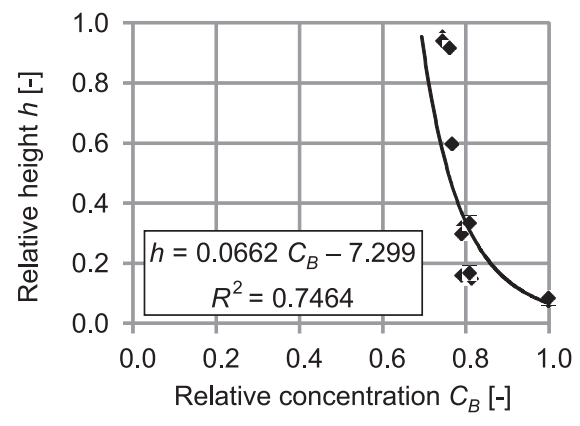

b) cross-section p-2

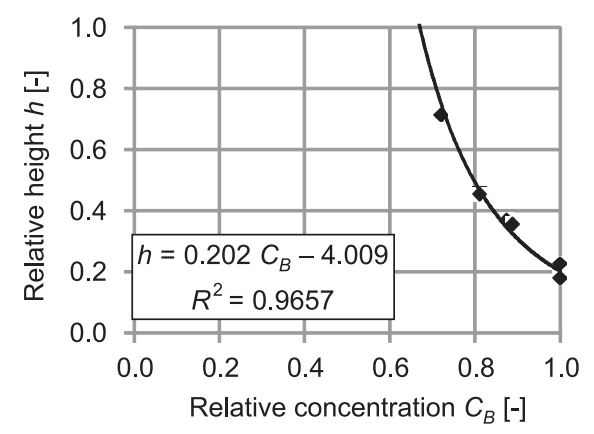

d) cross-section $p-4$

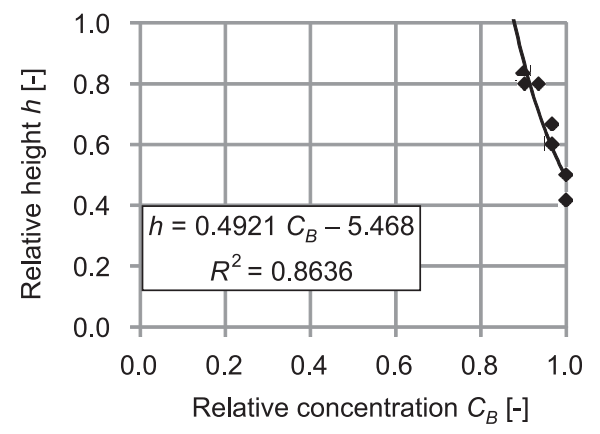

f) cross-section $p-6$

Fig. 6. Sediment concentration profiles in measurement cross-sections - measurement no. XIII conducted on 30 October 2016 
0.7, 0.6 and 0.67 , respectively. Figure 6 presents the concentration profiles in the measurement cross-sections, developed on the basis of the results of measurement no. XIII, made on 30 October 2016. In cross-section $\mathrm{p}-1$ in the surface area, the relative average concentration, determined from the regression curve (see: Fig. 5a), is 0.64 . The relative mean difference of concentrations in the demersal zone, determined according to the same regression curve (see: Fig. 5a), is 1.0. Therefore, the variation of vertical concentration values, which is the difference of these relative values, is 0.36 of the relative concentration value. In the p-2 section, the variation of the concentration in the concentration profile is 0.31 , in the $\mathrm{p}-5$ section it is 0.42 , whereas in the p-7 section it is 0.34 .

\section{DISCUSSION}

Determination of suspended sediment transport conditions in the drainage system by means of distribution of suspended sediment concentration, or sediment concentration profiles in individual cross-sections of the ditches is of high significance to calculating sediment transport. Determining the intensity of sediment transport in the drainage system is an important issue in assessing the stability or susceptibility of ditch beds to transformations resulting from shore and bottom erosion or sediment accumulation. Proper definition of the conditions for the beginning of sediment movement, flow rate, and conditions of deposition or sedimentation, is an important element in designing hydraulic structures in drainage systems.

Sediment transport is determined not only on the basis of direct measurements of the suspension concentration using bathometers, but is also calculated on the basis of the vertical sediment concentration distribution equations proposed by van Rijn (1987), Liu (2001) and Vanoni (2006). A model for calculating sediment transport in the drainage system using the Rijn equation (1987) to determine the concentration at the reference level relative to the bottom was presented by Lappalainen et al. (2010). This paper presents the application of determining the height of the bottom roughness in ditches according to van Rijn (1987) and Liu (2001), which equals between $2 d_{50}$ and $100 d_{50}$, depending on the bottom form. This means that in the case of the Łaczany drainage system, which is under examination here, it will be possible to verify the applicability of the model developed by Lappalainen et al. (2010), based on the pre-developed concentration profiles.

\section{CONCLUSIONS}

Based on the measurements of sediment concentration in the measurement cross-sections, it was found that in each of seven cross-sections there is a variation of sediment volumetric concentration. This is indicated by the values of the correction factor " $k$ ", calculated on the basis of point measurements as well as throughout the measurement cross-section. The values of this coefficient are from 1.188 to 1.328 . This means that in the calculation of suspended sediment transport in the ditches of the tested drainage system, using the normal method (Brański, 1975), it is necessary to take into account the variation in the concentration of the sediment in the cross-section of the ditch. Differences in the volumetric concentration of suspended sediment in hydrometric divisions (verticals) were also found. These concentrations, measured in surface layers, regardless of the height of vertical filling, represented on average about $60 \%$ of the value of the concentration measured in the bottom layers of verticals, i.e. about 5 $\mathrm{cm}$ above the bottom.

Continuation of the conducted tests, together with the test results obtained in the Łączany drainage system, will allow the calibration of the van Rijn equation (1987). As a result of this calibration, it will be possible to determine the sediment concentration at the reference level above the bottom, and then calculate the sediment transport intensity in drainage systems.

\section{REFERENCES}

Bates, D. M., Watts, D. G. (1988). Nonlinear regression analysis and its applications. New York: Wiley.

Brański, J. (1966). Instrukcja oznaczania unosin metodą wagową bezpośrednią przy użyciu sączków. Materiały PIHM do użytku wewnętrznego.

Brański, J. (1975). Ocena denudacji dorzecza Wisły na podstawie wyników pomiarów rumowiska unoszonego. Prace PIHM nr 6, Warszawa, 57.

Budowa pompowni dla rowu R - Łączany. (1975). Ekspertyza. Biuro Projektów Wodnych Melioracji w Krakowie. Maszynopis, Kraków. 
Michalec, B., Strutyński, M. (2019). Determining the conditions of suspended sediment flow in a drainage system. Acta Sci. Pol., Formatio Circumiectus, 18 (3), 49-58. DOI:

Forester, D. L., Girmai, I. (1980). Sediment Deposits in Drainage Ditches. Technical Report Series. The Ohio State University and Ohio Aqricultural and Research Development Center.

Kiryluk, A. (2013). Urządzenia melioracyjne ich stan i rola w ekoinżynierii i ochronie środowiska obszarów rolniczych województwa podlaskiego. Inżynieria Ekologiczna, 40, 2014, 33-43

Kiryluk, A. (2013). Wpływ robót konserwacyjnych na gatunki roślin w rowach melioracyjnych na pobagiennym obiekcie łąkowym. Przegląd Naukowy - Inżynieria i Kształtowanie Środowiska, 62, 374-381.

Lappalainen, M., Koivusalo, H., Karvonen, T., Laurén, A. (2010). Sediment transport from a peatland forest after ditch network maintenance: a modelling approach. Boreal Env. Res. 15, 595-612.

Liberacki, D., Olejniczak, M. (2013). Ocena potrzeb renowacji i modernizacji urządzeń wodno-melioracyjnych zlokalizowanych na wybranych ciekach w Puszczy Zielonka. Rocznik Ochrona Środowiska, 15, 930-943.

Majerczyk, A., Michalec, B. (2017). Oddziaływanie przepustów na warunki hydrauliczne przepływu wody w głównym rowie systemu odwadniającego stopnia wodnego Łączany. Przegląd Naukowy - Inżynieria i Kształtowanie Środowiska, 26(1), 28-37.

Michalec, B. (2012). Określenie przyczyny zagrożenia powodziowego terenów znajdujących się w strefie oddziaływania stopnia wodnego Łączany. Acta Scientiarum Polonorum, Formatio Circumiectus, 11(4), 83-90.

Michalec, B. (2018). Determination of sediment delivery ratio in draining system. Acta Scientiarum Polonorum, Formatio Circumiectus, 17(4), 131-141.

Michalec, B., Wałęga, A., Cupak, A. (2013). Retencja zbiornikowa $\mathrm{w}$ ochronie przeciwpowodziowej terenów systemu odwadniającego stopnia wodnego Łączany na Wiśle. Infrastruktura i Ekologia Terenów Wiejskich, Nr 3/ IV, Kraków, 177-190.

Pierzgalski, E., Jeznach, J., Baryła, A., Brandyk, A., Stańczyk, T., Szejba, D., Wiśniewski, S. (2012). Weryfikacja systemów melioracyjnych pod kątem znaczenia dla bezpieczeństwa powodziowego $\mathrm{w}$ regionie wodnym Wisły Środkowej. Opracowanie wykonane na zlecenie Mazowieckiego Urzędu Wojewódzkiego w Warszawie na potrzeby Programu Bezpieczeństwa Powodziowego w Dorzeczu Wisły Środkowej. Warszawa: SGGW.

Rytlewski, M. (2007). Stan ewidencyjny, plany i możliwości oraz utrzymanie urządzeń wodno-melioracyjnych. Wyd. Mel. i Łąk. Nr 1, 3-4.

Walczak, N., Hämmerling, M., Bykowski, J., Walczak, Z. (2015). Ekonomiczne i hydrauliczne kryteria utrzymania dobrego stanu rowów melioracyjnych. J. Agribus. Rural Dev., 1(35), 137-146.

\section{OKREŚLENIE WARUNKÓW PRZEPŁYWU RUMOWISKA UNOSZONEGO W SYSTEMIE ODWODNIE- NIOWYM}

\section{ABSTRAKT}

\section{Cel pracy}

W pracy podjęto próbę określania warunków przepływu rumowiska w systemie odwodnieniowym stopnia wodnego w Łączanach na Wiśle. W tym celu opracowano rozkład koncentracji rumowiska unoszonego w przekrojach poprzecznych rowów systemu odwadniającego, opracowano profile koncentracji rumowiska unoszonego w poszczególnych przekrojach poprzecznych głównego rowu, a także dokonano oceny zróżnicowania wartości koncentracji w profilach koncentracji w wyznaczonych przekrojach poprzecznych na całej długości głównego rowu R systemu odwadniającego w Łączanach.

\section{Materiał i metody}

W rowie R systemu wyznaczono cztery pomiarowe przekroje poprzeczne p-1, p-2, p-5 i p-7, a na dopływach do rowu R wyznaczono trzy przekroje pomiarowe. Punktowe pomiary koncentracji objętościowej rumowiska unoszonego w przekrojach wykonano zgodnie z metodyką poboru prób wody z użyciem batometrów butelkowych. Pomiary wykonano zarówno w całym przekroju za pomocą wcześniej wykalibrowanego fotooptycznego przyrządu Portable Suspended Solids Monitor 740 firmy Partech. Wyniki tych pomiarów umożliwiły wyznaczenie współczynnika korekcyjnego (k) dla każdego z przekrojów pomiarowych. 
Michalec, B., Strutyński, M. (2019). Determining the conditions of suspended sediment flow in a drainage system. Acta Sci. Pol., Formatio Circumiectus, 18 (3), 49-58. DOI: http://dx.doi.org/10.15576/ASP.FC/2019.18.4.49

\section{Wyniki i wnioski}

Stwierdzono, że wartości tego współczynnika (k) wynoszą od 1,188 do 1,328, co oznacza, że w obliczeniach transportu rumowiska unoszonego w rowach badanego systemu odwadniającego za pomocą tzw. metody normalnej konieczne jest uwzględnienie zróżnicowania koncentracji tego rumowiska w przekroju poprzecznym rowu. Stwierdzono również zróżnicowanie wartości koncentracji objętościowej rumowiska unoszonego w pionach hydrometrycznych. Koncentracje te, pomierzone w warstwach przypowierzchniowych, niezależnie od wysokości napełniania w pionie, stanowiły średnio około $60 \%$ wartości koncentracji pomierzonych w warstwach przydennych pionów, tj. około $5 \mathrm{~cm}$ nad dnem.

Słowa kluczowe: koncentracja rumowiska unoszonego, rów, profil koncentracji 